\title{
Startup Project Leadership dalam Meningkatkan Produktivitas Pembelajaran di Masa Pandemi
}

\author{
Startup Project Leadership in Increasing Learning Productivity in a Pandemic Period
}

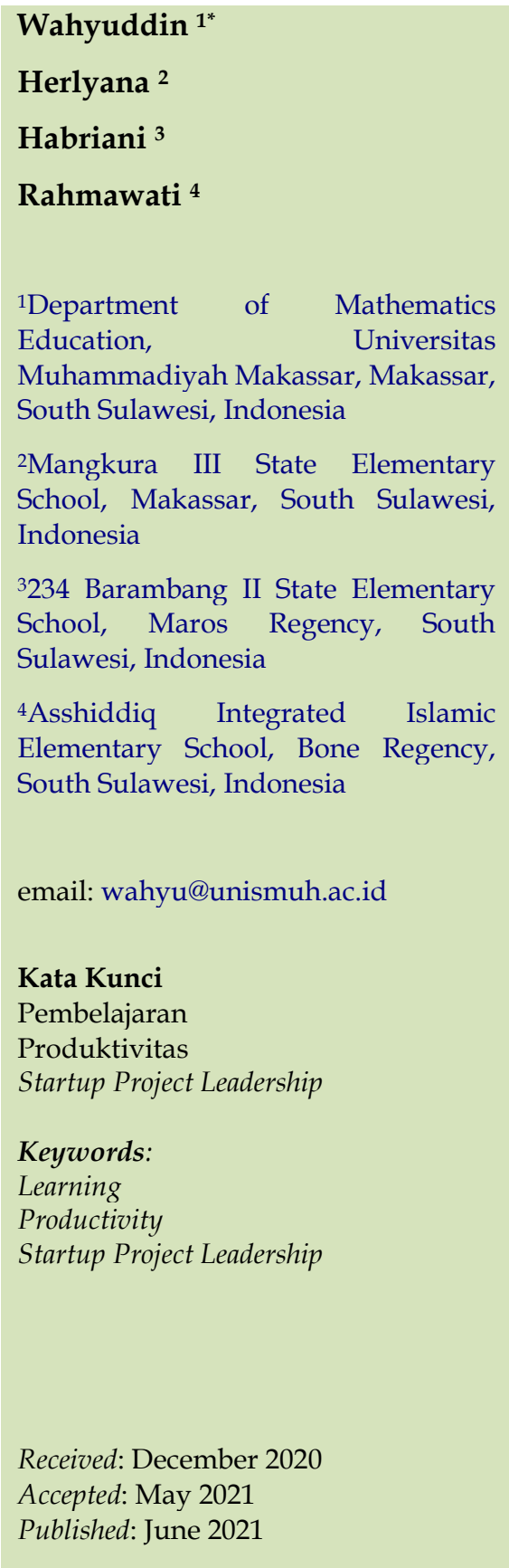

\begin{abstract}
Abstrak
Permasalahan pembelajaran di tengah pandemik cenderung satu arah dimana dimana guru lebih banyak memberi informasi satu arah dan tugas kepada siswa tanpa umpan balik yang berakibat pada munculnya perasaan bosan siswa belajar secara online. Oleh karena itu diberikan satu solusi melalui program startup project leadership (SPL). Kegiatan ini dilaksanakan pada Tanggal 31 Oktober-27 November 2020 pada 3 sekolah dasar: SDN Mangkura III Kota Makassar, SDN 234 Barambang II Kabupaten Maros, dan SD IT Asshiddiq Kabupaten Bone dengan melibatkan sebanyak 40 siswa. Hasil kegiatan dapat disimpulkan bahwa Program SPL merupakan aksi kolaborasi guru dalam berinovasi menciptakan pendidikan yang berkualitas di era pandemi terdiri dari 3 tahapan: Inkubasi yang merupakan perencanaan awal yang dilakukan dengan merancang kegiatan bersama dengan siswa dan orang tua siswa terkait permasalahan yang dihadapi siswa serta solusi yang akan diterapkan; Startup yang merupakan kegiatan tindakan realisasi program yang disepakati pada tahap inkubasi; dan Mobilisasi yang merupakan tahap akhir melalui merefleksi proses, evaluasi, dan penarikan kesimpulan, serta tindak lanjut terhadap hasil realisasi program yang telah dilakukan; serta Pelaksanaan SPL berjalan dengan baik sesuai waktu dan target yang telah ditentukan serta dapat meningkatkan produktivitas pembelajaran dimasa pandemi.
\end{abstract}

\begin{abstract}
Learning problems amid a pandemic tend to be one-way. Teachers provide more one-way information and assignments to students without feedback, resulting in boredom for students studying online. Therefore, one solution is given through the startup project leadership (SPL) program. This activity was held on October 31 - November 27, 2020, at three elementary schools: SDN Mangkura III Makassar, SDN 234 Barambang II Maros Regency, and SD IT Asshiddiq Bone Regency, involving as many as 40 students. The results of the activity can be concluded that the SPL Program is a collaborative action of teachers in innovating to create quality education in the pandemic era consisting of 3 stages: Incubation which is the initial planning carried out by designing joint activities with students and parents related to the problems faced by students and solutions that will be applied; Startup which is an active activity for program realization agreed at the incubation stage; and Mobilization which is the final stage through process reflection, evaluation, and conclusion drawing, as well as follow-up to the results of program realization that have been carried out. The implementation of SPL is running well according to the time and targets that have been determined and can increase learning productivity during pandemics.
\end{abstract}




\section{PENDAHULUAN}

Situasi pandemi terjadi saat ini akibat wabah corona virus (Covid-19) yang mulai merebah keseluruh dunia pada awal Tahun 2020 telah menimbulkan banyak dampak di berbagai sektor seperti kesehatan, perekonomian, dan pendidikan, hal tersebut juga terjadi di Indonesia. Menyikapi fenomena tersebut dan untuk mengantisipasi penyebaran Virus Covid-19, maka pemerintah Republik Indonesia melalaui Menteri Pendidikan dan Kebudayaan telah mengeluarkan kebijakan melalaui Surat Edaran Nomor 4 Tahun 2020 tentang pelaksanaan kebijakan pendidikan dalam masa darurat Penyebaran Covid-19. Salah satu poinnya adalah pembelajaran tatap muka disekolah untuk sementara ditiadakan dan digantikan dengan proses belajar dari rumah yang dilaksanakan melalui pembelajaran daring/jarak jauh untuk memberikan pengalaman belajar yang bermakna bagi siswa, tanpa terbebani tuntutan menuntaskan seluruh capaian kurikulum untuk kenaikan kelas maupun kelulusan (Anugrahana, 2020).

Upaya tersebut dilakukan pemerintah dengan tujuan untuk memastikan bahwa proses pembelajaran di tingkat satuan pendidikan harus tetap berjalan sesuai dengan standar yang telah ditetapkan pemerintah. Berbagai upaya yang telah dilakukan pemerintah untuk mendukung pembelajaran daring seperti pembagian kuota belajar bagi siswa, guru, dan dosen, kerjasama dengan penyedia layanan dalam hal penyediaan jaringan untuk mendukung pembelajaran online, serta pemberian bantuan biaya belajar bagi siswa, guru, dan dosen (Fauzi, 2020).

Namun upaya tersebut belum membuahkan hasil secara maksimal yang ditandai dengan berbagai permasalahan yang terjadi seperti sebagian orang tua peserta tidak memiliki perangkat handphone (android) atau computer untuk menunjang pembelajaran daring serta ketidaksiapan guru dan peserta didik terhadap pembelajaran daring (Asmuni, 2020). Jaringan yang tidak memadai (Hastini et al., 2020). Banyaknya tugas yang diberikan siswa yang bisa menghabiskan waktu dari pagi hingga malam hari (Oktawirawan, 2020). Tidak semua guru memiliki keterampilan literasi digital yang sama, ada guru yang relative lebih mampu beradaptasi, namun ada pula yang tidak mampu beradaptasi (Hamdani \& Priatna, 2020). Dan kesiapan, perancangan dan efektivitas e-learning masih belum dipahami dan belum siap dilaksanakan secara merata disetiap daerah (Wahyuddin et al., 2020).

Permasalahan yang sama juga diungkapkan oleh Organisasi Sekolah Guru Indonesia bahwa akar permasalahan pendidikan di tengah pandemik yang terjadi saat ini, yaitu Sekolah setengah lumpuh, masih kaku akibat teralienasi oleh iklim administrastif dan birokratis, Belum terwujudnya ekosistem pendidikan yang merupakan sinergi antara sekolah, keluarga, dan masyarakat, serta Masih lemahnya pengembangan profesional keguruan sabagai salah satu pilar dalam kemajuan pendidikan nasional (Sekolah Guru Indonesia, 2020).

Berbagai permasalahan tersebut tentu berbanding terbalik dengan proses pembelajaran yang diaharapkan sebagaimana yang ditentukan dalam standar proses pembelajaran berdasarkan Peraturan Pemerintah Republik Indonesia Nomor 19 Tahun 2005 tentang Standar Nasional Pendidikan bahwa proses pembelajaran pada satuan pendidikan diselenggarakan secara interaktif, inspiratif, menyenangkan, menantang, memotivasi peserta didik untuk berpartisipasi aktif, serta memberikan ruang yang cukup bagi prakarsa, kreativitas, dan kemandirian sesuai dengan bakat, minat, dan perkembangan fisik serta psikologis peserta didik (Pemerintah Republik Indonesia, 2005). 
Permasalahan pembelajaran dimasa pandemi saat ini juga cenderung satu arah dimana guru lebih banyak memberi informasi dan tugas kepada siswa secara online, tentu hal tersebut juga tidak sesuai dengan konsep pembelajaran yaitu proses interaksi peserta didik dengan pendidik dan sumber belajar pada suatu lingkungan belajar, sebagaimana pendapat Sagala (2009) bahwa pembelajaran adalah membelajarkan siswa menggunakan asas pendidikan maupun teori belajar yang merupakan penentu utama keberhasilan pendidikan, pembelajaran merupakan proses komunikasi dua arah dimana mengajar dilakukan pihak guru sebagai pendidik sedangkan belajar oleh peserta didik. Permasalahan pembelajaran yang tidak intraktif di masa pandemi juga tidak sesuai harapan sebagaimana yang dituangkan dalam Peraturan Pemerintah Nomor 19 Tahun 2005 tentang Standar Pendidikan Nasional bahwa proses pembelajaran haras diselenggarakan secara interaktif, inspiratif, menyenangkan, menantang, memotivasi peserta didik untuk berpartisipasi aktif, serta memberikan ruang yang cukup bagi prakarsa, kreativitas, dan kemandirian sesuai dengan bakat, minat, dan perkembangan fisik serta psikologis peserta didik, (Pemerintah Republik Indonesia, 2005).

Berkaitan dengan hal tersebut, maka dalam proses pembelajaran harus diterapkan strategi pembelajaran yang menyenangkan sebagaimana yang diungkapkan De Porter bahwa strategi pembelajaran yang menyenangkan adalah strategi yang digunakan untuk menciptakan lingkungan belajar yang efektif, menerapkan kurikulum, menyampaikan materi dan memudahkan proses belajar (Darmansyah, 2010). Selain itu menyelenggarakan pembelajaran yang menyenangkan dalam kurikulum 2013 juga menekankan dengan pendekatan saintifik (scientific approach) yaitu model pembelajaran yang menggunakan kaidah keilmuan yang memuat serangkaian aktivitas pengumpulan data melalui observasi, menanya, eksperimen, mengolah informasi atau data, kemudian mengkomunikasikan (Kementerian Pendidikan dan Kebudayaan Republik Indonesia, 2014).

Berdasarkan permasalahan tersebut, maka perlu diberikan suatu solusi yang dapat meningkatkan produktivitas pembelajaran. Produktivitas pembelajaran merupakan pendekatan pembelajaran yang menantang siswa untuk menghasilkan produk kreatif sebagai re kreasi terhadap pemahaman topik yang telah dikaji (Wena, 2014). Pembelajaran produktif memiliki beberapa krakteristik diantaranya keterlibatan siswa secara intelektual dan emosional, siswa disorong untuk menemukan konsep yang sedang dikasji melalui penafsiran yang dilakukan seperti observasi, diskusi, dan percobaan, siswa diberi tanggungjawab untuk menyelesaikan tugas bersama, dan mendorong siswa untuk berdedikasi tinggi, kerja keras, antusias, dan percaya diri (Suryosubroto, 2009).

Oleh karena itu, untuk mengatasi akar permasalahan pembelajaran dimasa pandemi, Sekolah Guru Indonesia (SGI) mengusulkan kerangka pemikiran pembelajaran di masa depan dengan berpedoman pada 4 prinsip yaitu masalah nyata adalah sumber belajar yang paling pertama, ekosistem pendidikan adalah ruang kelas yang paling utama, belajar adalah memproduksi pengetahuan baru, dan pembelajaran adalah kerja sama Guru dan murid untuk sama-sama belajar serta sama-sama mengajar (Sekolah Guru Indonesia, 2020).

Untuk mewujudkan solusi yang ditawarkan Sekolah Guru Indonesia, maka dibuatlah satu program yaitu kolaborasi guru pemimpin yang merupakan aksi kolaborasi guru dalam berinovasi menciptakan pendidikan yang berkualitas di era pandemi dengan menerapkan siklus pembelajaran Startup Project Leadership (SPL). Startup project leadership adalah suatu siklus pembelajaran berbasis kolaborasi kepemimpinan 
guru bersama siswa dalam memecahkan permasalahan teraktual melalui rintisan usaha yang inovatif dan produktif. Startup Project Leadership adalah suatu siklus pembelajaran berbasis kolaborasi kepemimpinan guru bersama siswa dalam memecahkan permasalahan teraktual melalui rintisan usaha yang inovatif dan produktif. Siklus SPL ini terdiri dari 3 tahapan yaitu inkubasi, startup, dan mobilisasi (Sekolah Guru Indonesia, 2020).

Startup Project Leadership dikembangkan berdasarkan teori bahwa guru sebagai pemimpin dalam pembelajaran yang bertugas mengembangkan organization of learning, suksesnya pembelajarn tergantung kemampuan guru. Kepemimpinan guru sangat penting dalam proses pembelajaran untuk meningkatkan prestasi belajar siswa secara signifikan. Selain itu juga dapat membangun komunitas belajar serta menjadikan kelas sebagai kelas pembelajar (Pusat Pengembangan Tenaga Kependidikan Kementerian Pendidikan dan Kebudayaan Indonesia, 2014; Hamalik, 2009).

Selanjutnya pembalajaran kolaborasi merupakan bertujuan membangun pengetahuan siswa melalui dialog, saling membagi informasi atara sesama siswa dan guru sehingga siswa dapat meningkatkan kemampuan mental pada tingkat tinggi. Pembelajaran kolaboratif online menciptakan lingkungan belajar yang inovatif bagi siswa dalam ruang digital. Meskipun tidak bersama-sama secara fisik, namun pelajaran dan diskusi dapat disesuaikan dan disusun sedemikian rupa sehingga memfasilitasi pembelajaran akademis yang mendalam, melatih pemikiran kritis, dan meningkatkan keterampilan memecahkan masalah. Pendekatan pengajaran ini menciptakan rasa komunitas dan keterlibatan sosial dalam ruang kelas virtual yang mendorong pertumbuhan dan perkembangan pribadi siswa (Barton, 2020).

\section{METODOLOGI}

Kegiatan pengabdian kepada masyarakat ini dilaksanakan oleh guru dan pendidik yang tergabung dalam Sekolah Guru Indonesia pada Tanggal 31 Oktober - 27 November 2020. Kegiatan ini dilaksanakan pada 3 sekolah dasar yaitu SDN Mangkura III Kota Makassar, SDN 234 Barambang II Kabupaten Maros, dan SD IT Asshiddiq Kabupaten Bone dengan melibatkan sebanyak 40 siswa. Siklus SPL terdiri dari 3 tahapan:

1. Tahap pertama yaitu inkubasi. Inkubasi merupakan perencanaan awal yang dilakukan dengan merancang kegiatan bersama dengan siswa dengan cara berdiskusi dengan siswa dan orang tua siswa terkait permasalahan yang dihadapi siswa dalam pembelajaran serta potensi yang ada di lingkungan tempat tinggal siswa yang dapat digunakan untuk menyelesaikan permasalahan yang ada.

2. Tahap kedua yaitu startup. Startup merupakan kegiatan tindakan untuk melaksanakan dan merealisasikan semua program yang telah direncanakan dan disepakati pada tahap inkubasi

3. Tahap ketiga yaitu mobilisasi. Mobilisasi merupakan tahap akhir dari proses SPL dimana guru bersama siswa dan orang tua merefleksi proses, evaluasi, dan penarikan kesimpulan, serta tindak lanjut terhadap hasil realisasi program yang telah dilakukan.

\section{HASIL DAN PEMBAHASAN}

Kegiatan SPL di SDN Mangkura III Kota Makassar

Kegiatan SPL di SDN Mangkura III Kota Makassar dilaksanakan pada kelas 2, melibatkan 15 siswa dengan tema "SINI BERDIRI (Sejak Dini Bersihkan Rumah Sendiri)" dengan tahapan kegiatan berikut:

1. Tahap inkubasi. Pada tahap inkubasi, tim melakukan diskusi dengan dengan siswa dan orang tua siswa terkait permasalahan yang dihadapi siswa yang berkaitan dengan materi hidup bersih dan sehat 
dirumah. Dari hasil diskusi diidentifikasi beberapa permasalahan diantaranya:

a. Pembelajaran sebelumnya hanya memberikan teori dan konsep tentang hidup bersih dan sehat dirumah tanpa ada pengalaman langsung siswa

b. Siswa belum terbiasa membersihkan tempat tidur dan tempat belajar secara mandiri.

c. Siswa belum terbiasa membersihkan rumah dan lingkungan sendiri.

d. Orang tua jarang atau tidak melibatkan anaknya dalam kegiatan membersihkan rumah dan lingkungan

e. Sehingga dari permasalahan tersebut, ditawarkan suatu solusi untuk siswa yaitu kegiatan "SINI BERDIRI" pada kegiatan tersebut belajar tentang hidup bersih dan sehat dirumah bukan hanya sekedar teori dan hanya pembelajaran konsep semata namun siswa langsung memperaktekkan kegiatan dan kebiasaaan hidup bersih dan sehat dirumah melalaui bimbingan orang tua dan guru.

2. Tahap kedua yaitu startup. Startup pelaksanaan program "SINI BERDIRI". Adapun tahapan yang dilakukan pata tahap startup yaitu:

a. Guru mensosialisasikan agenda dan tahapan kegiatan startup kepada siswa dan orangtua.

b. Siswa menulis agenda tentang ruangan dan lingkungan mana yang akan dibersihkan siswa.

c. Siswa membuat peraturan untuk diri sendiri serta seluruh anggota keluarga dirumah.

d. Menetapkan kegiatan rutin dalam rangka mewujudkan program hidup bersih dan sehat dirumah yaitu:

1) Kegiatan pagi yaitu membersihkan tempat tidur, membersihkan kamar mandi, menyapu halaman, membuang sampah pada tempatnya, menanam sayuran, dan menyiram tanaman.

2) Kegiatan sore yaitu menyiram tanaman, menyapu halaman, memilah sampah.

e. Siswa melaksanakan kegiatan yang telah disepakati dengan membuat dokumentasi semua kegiatan yang dipantau oleh orang tua dan dilaporkan secara berkala kepada guru. Adapun pelaksanaan kegiatan yang telah dilakukan siswa dapat dilihat pada dokumentasi berikut.

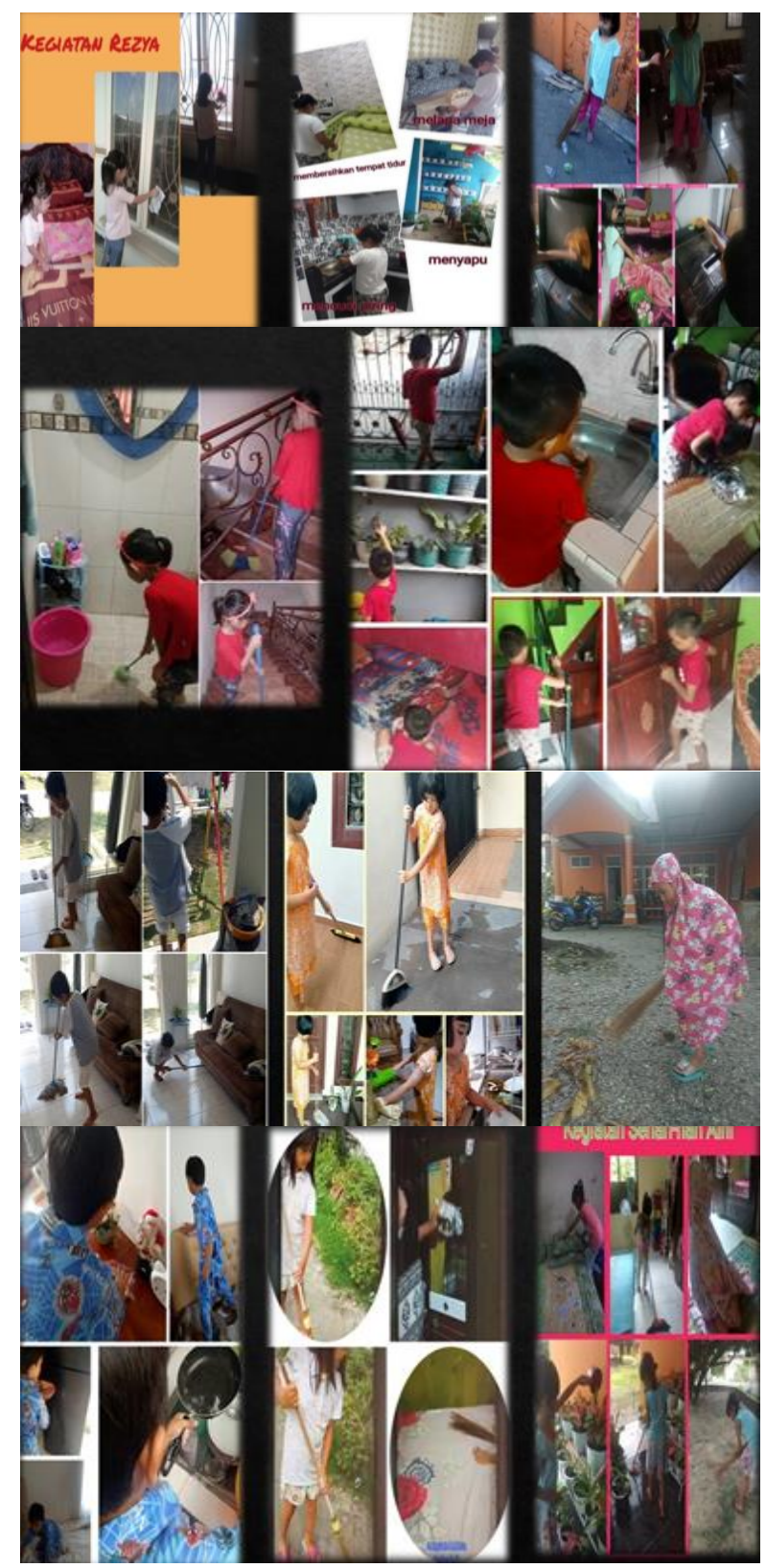

Gambar 1. Dokumentasi Foto Kegiatan Siswa pada Program SINI BERDIRI 
3. Tahap ketiga yaitu mobilisasi. Pada tahap mobilisasi ini dilakukan refleksi proses, evaluasi, dan penarikan kesimpulan, serta tindak lanjut terhadap hasil realisasi program yang telah dilakukan dengan simpulan sebagai berikut:

a. Pelaksanaan SPL dengan tema "SINI BERDIRI" berjalan dengan baik sesuai waktu dan target yang telah ditentukan.

b. Pada kegiatan tersebut banyak memberi dampak terhadap perilaku siswa dimana siswa sudah aktif dan terlibat langsung dalam kegiatan mewujudkan hidup bersih dan sehat dirumah. Sehingga dengan kegiatan tersebut dapat meningkatkan sikap disiplin, tanggungjawab, peduli, dan percaya diri.

c. Respon siswa dalam kegiatan tersebut sangat positif, dimana siswa merasa senang karena dapat secara langsung memperaktekkan materi pelajaran yang diberikan oleh guru atau dengan kata lain bahwa pembelajaran tersebut bermakna bagi siswa. Respon positif juga disampaikan oleh orang tua siswa, orang tua siswa merasa senang karena dengan kegiatan tersebut sangat memberi perubahan perilaku siswa dimana terjadi intraksi positi antara orang tua dan siswa khususnya dalam mewujudkan hidup bersih dan sehat dirumah.

\section{Kegiatan SPL di SDN 234 Barambang II Kabupaten Maros}

Kegiatan SPL di SDN 234 Barambang II Kabupaten Maros dilaksanakan pada kelas 6 dengan melibatkan 10 orang siswa dengan mengangkat tema "MENU NANGKA (Menulis Itu Menyenangkan)" dengan tahapan kegiatan sebagai berikut:

1. Tahap inkubasi. Pada tahap inkubasi, tim melakukan diskusi dengan dengan siswa dan orang tua siswa terkait permasalahan yang dihadapi siswa yang berkaitan dengan keterampilan menulis siswa pada pelajaran Bahasa Indonesia. Dari hasil diskusi diidentifikasi beberapa permasalahan diantaranya:

a. Pembelajaran online yang berlangsung telah membuat kebanyakan siswa merasa bosan yang berdampak pada malasnya siswa mengerjakan tugas yang setiap pekan harus dikumpul untuk diperiksa oleh wali kelas masing-masing

b. Minat siswa untuk menulis masih rendah, karena siswa hanya akan mencoba menulis setelah ada perintah dari guru.

c. Siswa malam menulis khususnya dalam menulis tugas yang telah diberikan oleh guru.

Sehingga dari permasalahan tersebut, ditawarkan solusi untuk siswa yaitu kegiatan "MENU NANGKA" pada kegiatan tersebut belajar keterampilan menulis siswa langsung bentuk praktek melalui bimbingan orang tua dan guru

2. Tahap kedua yaitu startup. Startup pelaksanaan program "MENU NANGKA". Adapun tahapan yang dilakukan pata tahap startup yaitu:

a. Guru mensosialisasikan agenda dan tahapan kegiatan startup kepada siswa dan orangtua.

b. Guru memberikan arahan kepada siswa tentang pentinya menulis serta langka-langkah menulis dengan cara mengarahkan siswa untuk mulai menuangkan seluruh perasaannya dalam buku sehingga siswa bisa curhat sepuasnya dalam bentuk tulisan. Kebiasaan MENU NANGKA yang dikemas dalam bentuk menulis diari inilah yang nantinya akan membangkitkan kembali minat menulis pada siswa.

c. Siswa melaksanakan kegiatan menulis yang telah disepakati dengan membuat dokumentasi semua kegiatan yang dipantau oleh orang tua dan dilaporkan secara berkal kepada guru. Adapun pelaksanaan kegiatan yang dilakukan siswa dapat dilihat pada dokumentasi berikut. 


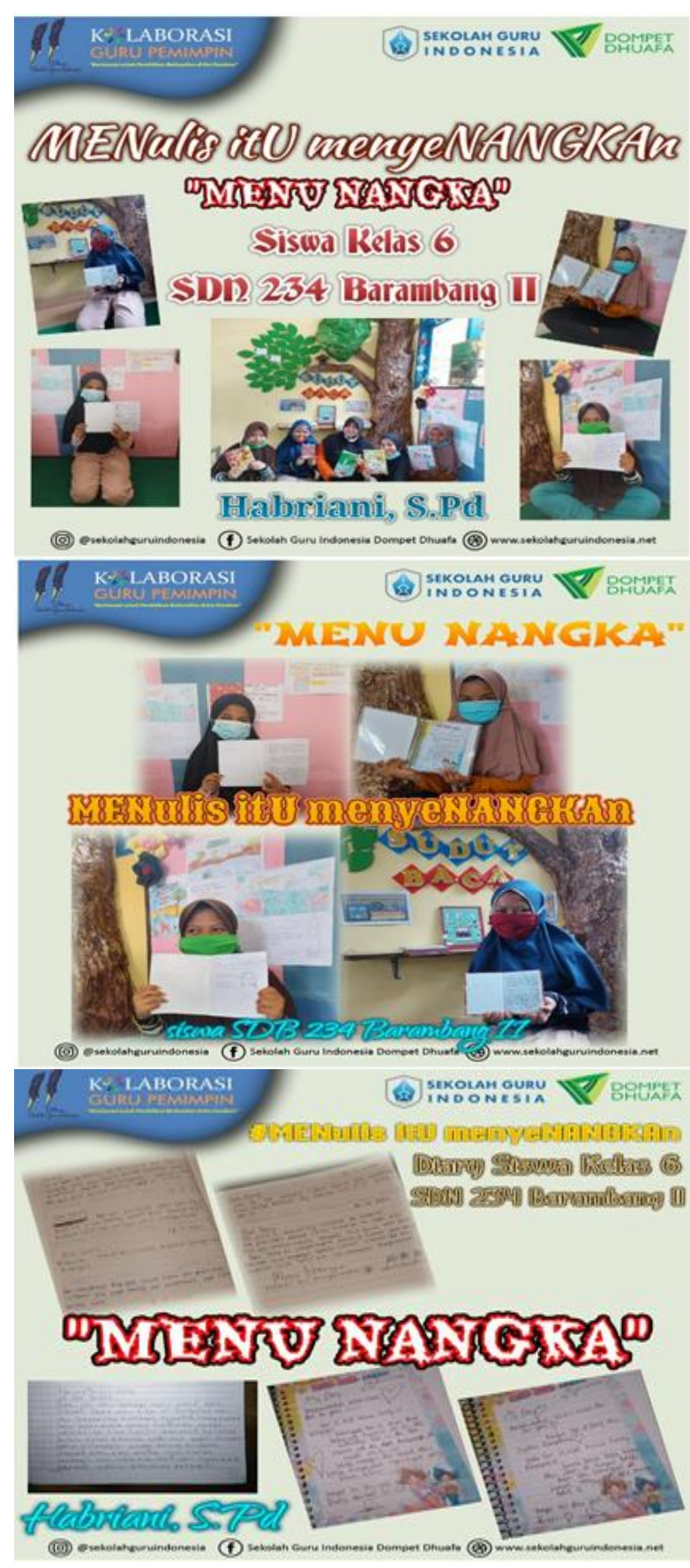

Gambar 2. Dokumentasi Foto Kegiatan Siswa pada Program MENU NANGKA

3. Tahap ketiga yaitu mobilisasi. Pada tahap mobilisasi ini dilakukan refleksi proses, evaluasi, dan penarikan kesimpulan, serta tindak lanjut terhadap hasil realisasi program yang telah dilakukan dengan simpulan sebagai berikut:

a. Pelaksanaan SPL dengan tema "MENU NANGKA" berjalan dengan baik sesuai waktu dan target yang telah ditentukan. b. Menurut beberapa siswa yang mengikuti proses SPL ini mengaku selain minat menulisnya sudah mulai kembali. Salah satunya yaitu Rara yang merasakan perubahan pada tulisannya yang semakin rapi, sedangkan Melati merasakan dampak pada daya ingatnya yang bertambah kuat dan mampu merangkai kata karna menulis diarynya sebelum tidur yang mengharuskannya untuk mengingat apa yang telah terjadi seharian sebelum menuangkan dalam bentuk tulisan. Selain itu orang tua siswa juga merasakan dampak pisitif seperti yang disampaikan orang tua Rezki Athira mengaku bahwa selama Rezky mengikuti SPL ini, baru mengetahui bahwa dibalik sikap pendiam anaknya, begitu banyak cerita yang dimiliki namun tidak berani menyampaikan kepada orang tua karena takut.

c. Secara umum minat menulis siswa meningkat setelah mengikuti SPL ini sehingga keterampilan menulis siswa pada pelajaran Bahasa Indonesia juga dapat meningkat.

\section{Kegiatan SPL di SD IT Asshiddiq Kabupaten Bone}

Kegiatan SPL di SD IT Asshiddiq Kabupaten Bone dilaksanakan pada kelas 1 dengan melibatkan 15 orang siswa dengan mengangkat tema "Berkah Kebiasaan Baik Sejak Dini" dengan tahapan kegiatan sebagai berikut:

1. Tahap inkubasi. Pada tahap inkubasi, tim melakukan diskusi dengan dengan siswa dan orang tua siswa terkait permasalahan yang dihadapi siswa yang berkaitan dengan menanamkan kebiasaan yang baik kepada siswa. Dari hasil diskusi diidentifikasi beberapa permasalahan diantaranya:

a. Pembelajaran online saat ini tidak maksimal mengajarkan kebiasaan yang baik kepada siswa

b. Perlu ada praktik langsung yang harus dikerjakan siswa dalam membiasan diri melakukan kebiasaan yang baik. 
c. Menanamkan kebiasaan baik merupakan tugas setiap orang tua dan pendidik. Pembiasaan ini merupakan salah satu aspek penting dlam pembentukan karakter anak, yang diperoleh melalui keteladanan dan usaha terus-menerus dalam membangun perilaku tersebut, sehingga harus diwujudkan dalam kehidupan sehari-hari.

d. Dengan menerapkan pembiasaab baik diharapkan akan membuahkan kepribadian yang mengagumkan dikemudian hari. Menanam kebiasaan-kebiasaan baik ini, sekalipun tidak sulit, namun membutuhkan komitmen dan konsistensi. Kita tidak perlu memulai dengan hal-hal yang memberatkan, kita bisa menanamkan kebiasaan-kebiasaan baik dari hal-hal sederhana, seperti tidak membuang sampah sembarangan, membantu orang tua, pembiasaan adab, dan mengajarkan anak sholat wajib atau sunnah, mengaji dan amalan lannya yang dapat mendatangkan keberkahan.

Sehingga dari permasalahan tersebut, ditawarkan suatu solusi untuk siswa yaitu kegiatan "Berkah Kebiasaan Baik Sejak Dini" pada kegiatan tersebut belajar tentang menanamkan kebiasaan yang baik kepada siswa melalui bimbingan orang tua dan guru.

2. Tahap kedua yaitu startup. Startup pelaksanaan program "Berkah Kebiasaan Baik Sejak Dini". Tahapan yang dilakukan pada tahap startup yaitu:

a. Guru memberi penguatan tentang membiasakan diri sejak dini untuk melakukan kegiatan baik.

b. Guru memberi tugas masing-masing siswa untuk melakukan kebiasaan baik setiap siswa melaporkan kegiatan baik setiap hari melalui cataan mereka dan setiap hari setor video kebaikan yang dilakukan agar siwa terlatih untuk terus melakukan kebiasaan yang baik.

c. Siswa merencanakan kebiasaan baik apa saja yang akan dilakukan atau yang akan dicapai oleh siswa.

d. Siswa di bimbing oleh orang tua untuk melakukan kebiasaan baik yang akan dilakukan (ada yang membiasakan diri bangun lebih awal, sholat dhuha atau sholat malam, rajin membantu orang tua, membiasakan adab dalam melakukan kegiatan atau kebiasaan baik yang lainnya).

e. Siswa mengimplementasikan rencana kebiasaan baik yang akan dilakukan.

f. Setiap siswa melaporkan kebiasaan baik apa saja yang sudah dilkukan. Adapun pelaksanaan kegiatan yang dilakukan siswa dapat dilihat pada dokumentasi berikut.

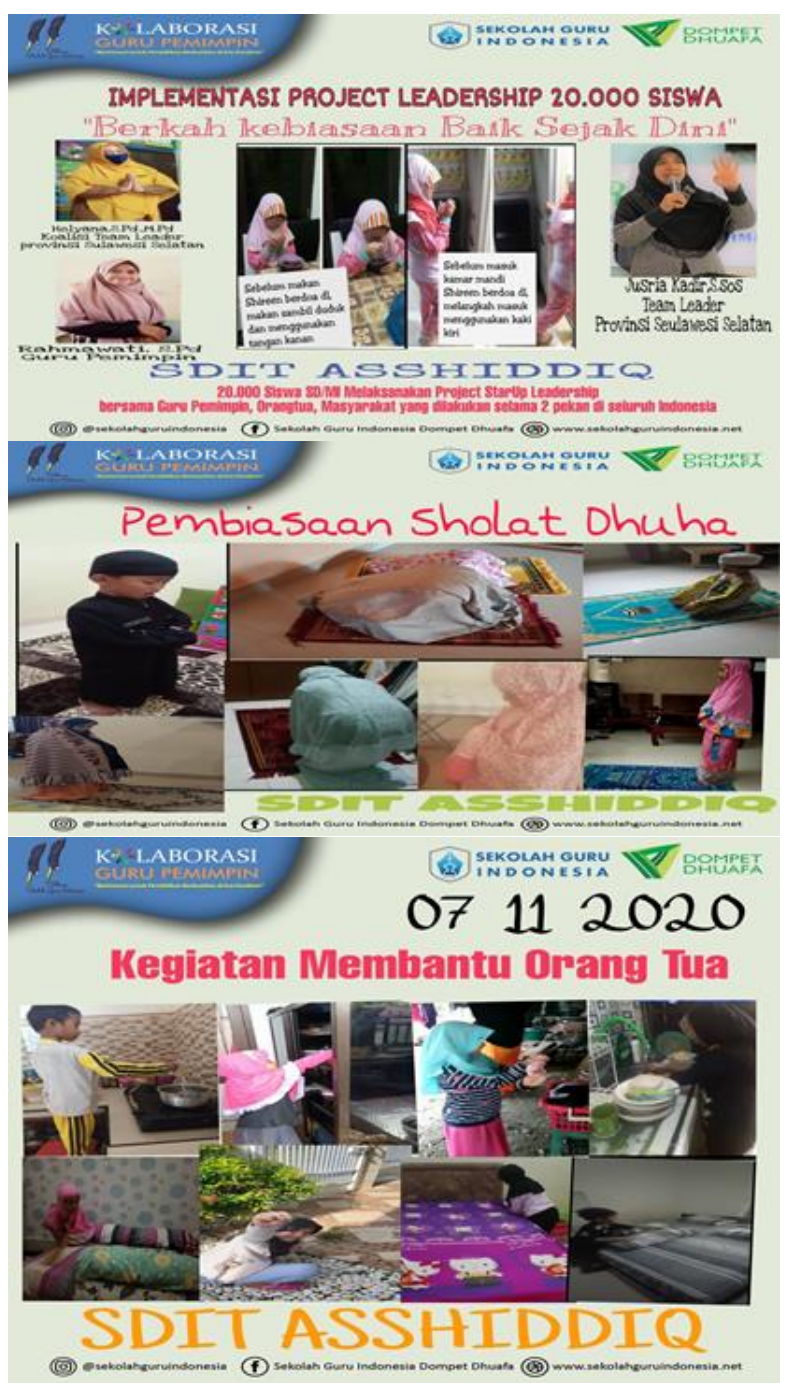

Gambar 3. Dokumentasi Foto Kegiatan Siswa pada Program Berkah Kebiasaan Baik Sejak Dini 
3. Tahap ketiga yaitu mobilisasi. Pada tahap mobilisasi ini dilakukan refleksi proses, evaluasi, dan penarikan kesimpulan, serta tindak lanjut terhadap hasil realisasi program yang telah dilakukan dengan simpulan sebagai berikut:

a. Pelaksanaan SPL dengan tema "Berkah Kebiasaan Baik Sejak Dini" berjalan dengan baik sesuai waktu dan target yang telah ditentukan.

b. Kegiatan SPL ini mampu untuk mengatasi permasalahan pembelajaran di masa pandemi Covid-19 terutama dalam pembentukan karakter anak dan kurangnya pembiasaan yang tertanamkan kepada anak. Suatu tindakan akan teraplikasi dengan baik, manakala, tindakan itu menejadi kebiasaan. Melalui kegiatan ini dapat menanamkan kebiasaan-kebiasaan baik pada anak agar membuahkan kepribadian yang mengagumkan dikumudian hari.

c. Orang tua sangat antusias dalam kegiatan ini mereka juga berusaha agar kegiatan ini selalu jadi pembiasaan kepada anak dan begitu juga dengan siswa berlomba- lomba untuk terus melakukan kebaikan.

d. Melalui kegiatan SPL ini apa yang dilakukan siswa setiap hari dapat merubah perilaku siswa menjadi sebuah kebiasaan baik sejak dini sehingga terbentuk karakter dan kedisiplinan siswa.

Berdasarkan hasil SPL yang dilaksanakan pada tiga lokasi sekolah yang berbeda dapat dijelaskan bahwa semua kegiatan berjalan dengan baik sesuai dengan target yang direncanakan. Lebih lanjut, pelaksanaan kegiatanSPL secara nyata dapat meningkatkan hasil dan produktivitas pembelajaran, hal tersebut dapat dilihat dari hasil program misalnya pada program "SINI BERDIRI" memberi dampak terhadap perilaku siswa dimana siswa sudah aktif dan terlibat langsung dalam kegiatan mewujudkan hidup bersih dan sehat dirumah. Selanjutnya pada program "MENU NANGKA" dapat meningkatkan minat siswa dalam menuis. Demikian juga halnya pada program “Berkah Kebiasaan Baik Sejak Dini" dapat menanamkan kebiasaan-kebiasaan baik pada anak dan membuahkan kepribadian yang baik.

Keberhasilan program tersebut, tidak terlepas dari perencanaan yang dilakukan pada tahap inkubasi yang dirancang dengan cara berdiskusi dengan siswa dan orang tua siswa terkait permasalahan yang dihadapi siswa dalam pembelajaran serta potensi yang ada di lingkungan tempat tinggal siswa yang dapat digunakan untuk menyelesaikan permasalahan yang ada, hal ini didukung dengan teori yang menjelaskan bahwa dengan perencanaan pembelajaran matang maka akan terhindar dari kegagalan pembelajaran, sebagai alat pemecah masalah, untuk memanfaatkan berbagai sumber belajar secara tepat (Sanjaya, 2013). Temuan ini juga sejalan dengan hasil penelitian (Novalita, 2014) yang menjelaskan bahwa terdapat pengaruh yang tinggi antara perencanaan pembelajaran terhadap pelaksanaan pembelajaran.

Demikian halnya juga pada tahap starup, dimana dalam pelaksanaan pembelajaran bukan hanya sekedar teori dan pembelajaran konsep semata namun dalam kegiatan ini mengimplementasikan pembelajaran kontekstual dan pembelajaran bermakna dimana siswa langsung memperaktekkan kegiatan seperti pada materi kebiasaaan hidup bersih dan sehat dirumah siswa langsung disuruh memperaktekkan bagaimana mewujudkan hidup bersih dan sehat di rumah. Hal ini sejalan dengan teori Ausabel melalui pembelajaran bermakna bahwa bahwa pembelajaran bagi peserta didik akan bermakna bila apa yang dipelajari oleh mereka berhubungan dengan apa yang diketahui dan dialaminya (Wachyu, 2014). Lebih lanjut, hasil penelitian ini juga sejalan dengan hasil penelitian Sudira (2020) 
yang menjelaskan bahwa bahwa pembelajaran kontekstual berbasis berpengaruh secara signifikan terhadap kompetensi pengetahuan PPKn siswa kelas V SD, dan hasil penelitian Fauzi (2017) bahwa pembelajaran kontekstual berbasis mind mapping memberikan pengaruh terhadap hasil belajar siswa. Dan tahap selanjutnya yaitu mobilisasi, tahap ini merupakan tahap akhir dari proses SPL dimana guru bersama siswa dan orang tua merefleksi proses, evaluasi, dan penarikan kesimpulan, serta tindak lanjut terhadap hasil realisasi program yang telah dilakukan.

Selanjutnya dari segi pelaksanaan kegiatan SPL ini berjalan dengan baik sesuai waktu dan target yang telah ditentukan serta dapat meningkatkan produktivitas pembelajaran dimasa pandemi. Namun pelaksanaan kegiatan ini juga memiliki beberapa keterbatasan dan kendala diantaranya program hanya bisa dilaksanakan dalam skala kecil dan hanya mengambil beberapa sampel kelas serta durasi waktu yang singkat sehingga hanya mengambil satu tema mata pelajaran disetiap program.

\section{KESIMPULAN}

Program SPL merupakan aksi kolaborasi guru dalam berinovasi menciptakan pendidikan yang berkualitas di era pandemi terdiri dari 3 tahapan yaitu inkubasi yang merupakan perencanaan awal yang dilakukan dengan merancang kegiatan bersama dengan siswa dan orang tua siswa terkait permasalahan yang dihadapi siswa serta solusi yang akan diterapkan, starup yang merupakan kegiatan tindakan realisasi program yang disepakati pada tahap inkubasi, dan mobilisasi yang merupakan tahap akhir melalui merefleksi proses, evaluasi, dan penarikan kesimpulan, serta tindak lanjut terhadap hasil realisasi program yang telah dilakukan. Pelaksanaan SPL berjalan dengan baik sesuai waktu dan target yang telah ditentukan serta dapat meningkatkan produktivitas pembelajaran dimasa pandemic.

\section{UCAPAN TERIMA KASIH}

Ucapan terima kasih yang sebesar-besarnya kepada Dompet Dhuafa yang telah merintis dan mendirikan Sekolah Guru Indonesia (SGI) yang berkomitmen melahirkan guru transformatif yang memiliki kompetensi mengajar, mendidik dan berjiwa kepemimpinan sosial. Sehingga melalaui SGI, maka aksi kolaborasi guru dalam berinovasi menciptakan pendidikan yang berkualitas di era pandemi dengan menerapkan siklus pembelajaran SPL dapat terlaksana dengan hasil yang baik. Terima kasi pula kami sampaikan kepada kepala sekolah SDN Mangkura III Kota Makassar, SDN 234 Barambang II Kabupaten Maros, dan SD IT Asshiddiq Kabupaten Bone, tim leader, koalisi team leader, guru pemimpin, serta para orang tua siswa atas kerjasamanya sehingga program ini dapat berjalan dengan baik.

\section{REFERENSI}

Anugrahana, A. 2020. Hambatan, Solusi dan Harapan: Pembelajaran Daring Selama Masa Pandemi Covid-19 Oleh Guru Sekolah Dasar. Scholaria: Jurnal Pendidikan Dan Kebudayaan. 10(3):282289.

https://doi.org/10.24246/j.js.2020.v10.i3.p282 $-289$

Asmuni. 2020. Problematika Pembelajaran Daring di Masa Pandemi Covid-19 dan Solusi Pemecahannya. Jurnal Paedagogy. 7(4):281-288. https://doi.org/10.33394/jp.v7i4.2941

Barton, T. 2020. The Future of Collaborative Learning. https://servelearn.co/blog/the-future-ofcollaborative-learning/

Darmansyah, D. 2010. Strategi Pembelajaran Menyenangkan Dengan Humor. Jakarta: Bumi Aksara 
Fauzi, M. 2020. Strategi Pembelajaran Masa Pandemi COVID-19 STIT Al-lbrohimy Bangkalan. AlIbrah: Jurnal Pendidikan dan Keilmuan Islam. 5(2):120-145.

Fauzi, Z.A. 2017. Pengaruh Pembelajaran Kontekstual Berbasis mind mapping terhadap hasil belajar siswa kelas IV di SDN Mawar 2 Banjarmasin. Thesis. Malang: Universitas Negeri Malang.

Hamalik, O. 2009. Proses Belajar Mengajar. Jakarta: Bumi Aksara

Hamdani, A.R., Priatna, A. 2020. Efektifitas Implementasi Pembelajaran Daring (Full Online) Dimasa Pandemi Covid-19 Pada Jenjang Sekolah Dasar Di Kabupaten Subang. Didaktik: Jurnal Ilmiah PGSD STKIP Subang. 6(1):1-9. https://doi.org/10.36989/didaktik.v6i1.120

Hastini, L.Y., Fahmi, R., Lukito, H. 2020. Apakah Pembelajaran Menggunakan Teknologi dapat Meningkatkan Literasi Manusia pada Generasi Z di Indonesia? Jurnal Manajemen Informatika (JAMIKA). 10(1):12-28. https://doi.org/10.34010/jamika.v10i1.2678

Kementerian Pendidikan dan Kebudayaan Republik Indonesia. 2014. Konsep dan Implementasi Kurikulum 2013. Jakarta: Kementerian Pendidikan dan Kebudayaan Republik Indonesia

Novalita, R. 2014. Pengaruh Perencanaan Pembelajaran Terhadap Pelaksanaan Pembelajaran (Suatu Penelitian terhadap Mahasiswa PPLK Program Studi Pendidikan Geografi FKIP Universitas Almuslim). Lentera: Jurnal Ilmiah Sains, Teknologi, Ekonomi, Sosial, dan Budaya. 14(2):56-61.

Oktawirawan, D.H. 2020. Faktor Pemicu Kecemasan Siswa dalam Melakukan Pembelajaran Daring di Masa Pandemi Covid-19. Jurnal Ilmiah Universitas Batanghari Jambi. 20(2):541-544. http://dx.doi.org/10.33087/jiubj.v20i2.932

Pemerintah Republik Indonesia. 2005. Peraturan Pemerintah Republik Indonesia Nomor 19 Tahun 2005 Tentang Standar Nasional Pendidikan

Pusat Pengembangan Tenaga Kependidikan Kementerian Pendidikan dan Kebudayaan Indonesia. 2014. Manajemen Dan Kepemimpinan Sekolah. Jakarta: Kementerian Pendidikan dan Kebudayaan Indonesia
Sagala, S. 2009. Konsep Dan Makna Pembelajaran, Cetakan VII. Bandung: Alfabeta

Sanjaya, S. 2013. Perencanaan Dan Desain Sistem Pembelajaran. Jakarta: Kencana Prenada Media Group

Sekolah Guru Indonesia. 2020. Kolaborasi Guru Pemimpin. https://www.sekolahguruindonesia.net/kol aborasi-guru-pemimpin/

Sudira, N.M.L.K. 2020. Pengaruh Pembelajaran Kontekstual Berbasis Multikultural Terrhadap Kompetensi Pengetahuan PPKN Siswa Kelas V SD Gugus VII Kecamatan Kuta Selatan Kabupaten Badung Tahun Ajaran 2019/2020. Thesis. Singaraja: Universitas Pendidikan Ganesha

Suryosubroto, B. 2009. Proses Belajar Mengajar Di Sekolah (Edisi Revisi). Jakarta: Bumi Aksara

Wachyu, S. 2014. Pembelajaran Berbasis Tema. Jakarta: Erlangga

Wahyuddin, Maharida, Jusriadi, E., Syafaruddin. 2020. Analysis of Motivation and How The Students Learn in Pandemic. PEDAGOGIA: Jurnal Pendidikan. $\quad$ 9(2):259-273. https://doi.org/10.21070/pedagogia.v9i2.570

Wena, M. 2014. Strategi Pembelajaran Inovatif Kontemporer. Jakarta: Bumi Aksara 